\title{
Las Comisiones Provinciales de Valoraciones de Andalucía
}

\section{$M^{\underline{a}}$ del Carmen Núñez Lozano}

Prof. Titular de Derecho Administrativo

\begin{abstract}
SUMARIO: I. INTRODUCCIÓN. II. LA COMPETENCIA DE LA COMUNIDAD AUTÓNOMA PARA CREAR Y REGULAR LAS COMISIONES PROVINCIALES DE VALORACIONES. III. NATURALEZA. IV. COMPOSICIÓN. V. FUNCIONES. VI. PROCEDIMIENTO. VII. EL INCUMPLIMIENTO DE LA OBLIGACIÓN DE ADOPCIÓN DEL ACUERDO EN PLAZO. VIII. EL ACUERDO DE FIJACIÓN DEL JUSTIPRECIO. IX. BIBLIOGRAFÍA.
\end{abstract}

\section{INTRODUCCIÓN}

El objeto de este trabajo es analizar la figura de las Comisiones Provinciales de Valoraciones, creadas por la Disposición Adicional Tercera de la Ley 7/2002, de 17 de diciembre, de Ordenación Urbanística de la Comunidad Autónoma de Andalucía (LOUA), que, de este modo, se suma a aquellas Comunidades que han creado y regulado sus propios órganos de fijación de justiprecios.

Se trata de una iniciativa ciertamente polémica, de la que ya he dado cuenta en otro lugar ${ }^{1}$, y que cabe en parte justificar en la actual incapacidad del Jurado Provincial de Expropiación para cumplir la misión que le fue asignada en la todavía vigente Ley de Expropiación Forzosa de 1954 (LEF). De hecho, la Exposición de Motivos de la LOUA menciona expresamente el "objetivo de mediar en el mercado del suelo, interviniendo con mayor rigor y agilidad en los procesos expropiatorios" y añade, más adelante, que "se pretende que sean un instrumento profesional y ágil en la resolución de las valoraciones de las expropiaciones”. En estos aspectos insiste también la Exposición de Motivos del Reglamento de Organización y Funcionamiento de las Comi-

1 "Los órganos autonómicos de fijación de justiprecios. Propuestas y sugerencias sobre el correcto ejercicio de la competencia estatal sobre legislación de expropiación forzosa”, pendiente de publicación. 
siones Provinciales de Valoración, dictado al amparo de los apartados tercero y quinto de la DA $3^{a}$ de la Ley y aprobado por Decreto 85/2004, de 2 de marzo $^{2}$.

Muy posiblemente haya pesado también en el ánimo del legislador andaluz el deseo de avanzar en el diseño organizativo de la Comunidad, en este caso mediante la creación y configuración de órganos propios, distintos de los estatales, para la realización de una función que se incardina en el ejercicio de una potestad propia.

Veamos, pues, los extremos más relevantes de la ordenación de estas nuevas Comisiones: naturaleza, composición, funciones, procedimiento, incumplimiento de la obligación de adopción del acuerdo en plazo y el acuerdo de fijación del justiprecio. Antes, sin embargo, conviene detenerse en una cuestión previa elemental, cual es la competencia de la Comunidad Autónoma para crear y regular estos órganos.

\section{LA COMPETENCIA DE LA COMUNIDAD AUTÓNOMA PARA CREAR Y REGULAR LAS COMISIONES PROVINCIALES DE VA- LORACIÓN}

La Comunidad Autónoma de Andalucía ha invocado las competencias de autoorganización, de desarrollo legislativo y ejecución en materia de expropiación forzosa y de régimen local, previstas en los arts. 13.1 y 3 y 15.1.2 del Estatuto de Autonomía, para justificar la creación y regulación de las Comisiones (Exposición de Motivos del Reglamento). Estas han sido, por otra parte, las competencias en que se han apoyado el resto de Comunidades que han explicitado sus títulos competenciales ${ }^{3}$.

Sin embargo, la Constitución señala que es competencia del Estado la legislación sobre expropiación forzosa (art. 149.1.18), de modo que no establece de modo expreso ningún reparto de las competencias legislativas entre el

\footnotetext{
${ }^{2}$ Señala que se "pretende posibilitar un funcionamiento ágil de las citadas Comisiones, así como también garantizar tanto la función de estos órganos como la seguridad jurídica de los ciudadanos en la tramitación del procedimiento".

${ }^{3}$ Cataluña y Extremadura , además, se han referido a las normas de procedimiento derivadas de la especialidad de su autoorganización.
} 
Estado y las Comunidades Autónomas. Atendiendo a la letra del art. 149.1.18, habría que concluir que Andalucía, como el resto de Comunidades que han creado y regulado sus propios órganos de valoración, ha incurrido en extralimitación competencial.

En mi opinión, no cabe extraer una consecuencia tan radical. Debe tenerse en cuenta, en efecto, que el título competencial no viene referido a un sector de actividad, sino a una potestad, lo que puede modular el alcance de la competencia estatal. Como ya he expuesto en otro lugar ${ }^{4}$, cabe distinguir entre la regulación de la institución propiamente dicha y la de aspectos de otras materias más amplias o generales que encuentran en su aplicación a la potestad -aquí la expropiatoria- expresiones particulares: me refiero a las normas de carácter procedimental o las que se ocupan del régimen jurídico de la Administración, materias sobre las que la competencia estatal no es exclusiva, por alcanzar sólo a lo común y a las bases. Y es aquí donde podríamos situar el caso de los órganos de valoración de justiprecios, cuya normación, por tanto, sólo correspondería al Estado plenamente respecto de los propios y parcialmente respecto de los autonómicos, esto es, en lo que pudiera calificarse como común (si entendemos que se trata de la regulación del procedimiento administrativo) o básico (si entendemos que se trata del régimen jurídico de las Administraciones públicas), de modo que sólo fije los principios y garantías de resultado que el órgano autonómico haya de incorporar y asegurar. Los demás extremos de su regulación estarían a disposición de las Comunidades Autónomas, que podrían optar por consiguiente por diferentes soluciones siempre que éstas respetaran, como es natural, el mínimo estatal.

Las Comunidades Autónomas pueden, pues, crear y regular sus propios órganos de valoración respetando la legislación estatal. Sucede, sin embargo, que esta normativa estatal no existe como tal, según he explicado en el trabajo antes citado, ya que no cabe atribuir a la regulación de los Jurados que ofrece la Ley de Expropiación Forzosa de 1954 el valor material de normas comunes o básicas ${ }^{5}$. Por consiguiente, no parece que pueda tacharse de inconstitucional la decisión de las Comunidades de crear y regular sus propios órganos, incluso aunque algunos de éstos no respondan a la composición del Jurado de

\footnotetext{
4 “Los órganos autonómicos ..." cit.

${ }^{5}$ En el estudio de referencia he destacado cómo la circunstancia de estar presidido por un Magistrado ha sido informada negativamente por el Consejo General del Poder Judicial, las críticas sobre su inoperancia e ineficacia, la pérdida de sus señas de identidad, al menos tal y como fueron proclamadas por la LEF y, en general, la necesidad de revisión de la figura.
} 
la LEF, como es el caso precisamente de la Comunidad de Andalucía: sencillamente, no hay hasta la fecha modelo alguno que respetar. La situación es la misma, por otro lado, que se origina en tantos otros casos cuando el Estado no legisla las bases de una materia: las Comunidades Autónomas pueden adelantarse y emanar la que a su juicio sería la legislación de desarrollo; la posterior aprobación de la normativa básica puede, en su caso, incidir sobre esas normas de desarrollo. Por tanto, las Comunidades han adelantado una determinada configuración de los órganos de valoración; en manos del Estado queda ejercer su competencia y avalar o desautorizar la acción autonómica, la concreta configuración que los órganos autonómicos han ido recibiendo.

En conclusión, pues, Andalucía, como las demás Comunidades Autónomas, puede crear sus órganos de valoración y regularlos dentro del minimo común normativo establecido por el Estado. En las circunstancias actuales carecemos de ese mínimo, de modo que la normativa andaluza no puede reputarse sin más como inconstitucional, máxime si el Estado mismo no ha impugnado otras normas autonómicas más que por razón de la presencia de miembros del Poder Judicial en los órganos de valoración ${ }^{6}$, paradójicamente -nótese tambiénen línea con la regulación del Jurado de la $\mathrm{LEF}^{7}$.

\footnotetext{
6 Se han recurrido la Ley de Ordenación del Territorio y Urbanismo de Castilla-La Mancha, de 4 de junio de 1998 y la Ley 9/1999, de 13 de mayo, de Ordenación Territorial de la Comunidad Autónoma de Canarias, en ambos casos, en lo que aquí interesa, porque otorgaban la presidencia del Jurado Regional de Valoraciones y de la Comisión de Valoraciones, respectivamente, a un Magistrado. El Tribunal Constitucional no ha llegado a pronunciarse sobre estos recursos, si bien por Auto 46/1999, de 25 de febrero, mantuvo la suspensión del precepto castellano manchego impugnado, al considerar la posible afectación a los intereses generales vinculados al funcionamiento de la Justicia; la Ley 1/2003, de 17 de enero, ha modificado el precepto, "habida cuenta de las discrepancias manifestadas sobre la capacidad de la ley autonómica para mantener la regla, tradicional en nuestro Derecho, de la atribución de la presidencia del órgano colegiado de valoraciones a un Magistrado, con la que se quiso preservar su independencia en garantía de la integridad del derecho de propiedad". También se ha suprimido la presencia del Magistrado en la Comisión de Valoraciones canaria (Ley 2/2000, de 17 de julio).

Ha de tenerse en cuenta que la STC 150/1998 había declarado la falta de competencia de Castilla y León para integrar a los Jueces de Primera Instancia en las Comisiones Locales de Concentración Parcelaria, por corresponder al Estado, art. 149.1.5 CE, la regulación de las funciones que hayan de desempeñar los Jueces y Magistrados, titulares del Poder Judicial, "sin que tal tacha quede obviada por la circunstancia de que la Ley de Reforma y Desarrollo Agrario, que es una norma estatal, contenga un mandato idéntico" (F.J. $2^{\circ}$ ). En parecidos términos, vid. la STC $127 / 1999$.

7 Vid. estas consideraciones, tratadas con mayor amplitud en "Los órganos autonómicos ...", cit.
} 


\section{NATURALEZA}

Las Comisiones Provinciales de Valoraciones se configuran como órganos colegiados permanentes, de naturaleza administrativa, de carácter desconcentrado y de ámbito provincial, especializados en materia de expropiación forzosa (DA 3 $3^{\mathrm{a}} .1$ LOUA y art. 1 del Reglamento).

Es el Reglamento el que señala el carácter permanente de las Comisiones, en línea con lo que disponen otras normas de Comunidades Autónomas ${ }^{8}$ que, como la nuestra, han optado por una configuración más técnica y profesionalizada de los órganos de valoración, como después habrá ocasión de comprobar.

Están adscritas a la Consejería de Gobernación, la cual debe facilitar la infraestructura administrativa necesaria para su adecuado funcionamiento (DA $3^{3} .1$ LOUA y art. 3.1 del Reglamento). Radican en las sedes de las Delegaciones del Gobierno de la Junta de Andalucía en cada una de las ocho provincias andaluzas (art. 3.2 del Reglamento).

Muy probablemente, la opción de adscribir las Comisiones a la Consejería de Gobernación obedezca a mera inercia, habida cuenta la histórica incardinación de los Jurados Provinciales de Expropiación en los Gobiernos Civiles y, ahora, en las Subdelegaciones Provinciales del Gobierno (Delegaciones del Gobierno en las Comunidades Autónomas unipersonales). Cabe plantearse, de todas formas, si no hubiera sido más adecuada su adscripción a la Consejería de Justicia y Administración Pública o a la de Obras Públicas ${ }^{9}$.

${ }^{8}$ Art. 12.1 del Decreto Legislativo 1/2004, de 22 de abril, del Principado de Asturias, que aprueba el Texto Refundido de las Disposiciones Legales vigentes en materia de Ordenación del Territorio y Urbanismo. Art. 1 del Decreto 41/2003, de 8 de abril, de Castilla-La Mancha. Art. 232 de la Ley 9/2002, de Ordenación Urbanística y Protección del Medio Rural de Galicia. Art. 1 del Reglamento de Organización y Funcionamiento del Jurado Territorial de Expropiación Forzosa de la Comunidad de Madrid. Art. 228.1 del Decreto Legislativo 1/2000, de 8 de mayo, de Canarias. Art. 418.1 del Reglamento de Urbanismo de Castilla y León.

\footnotetext{
${ }^{9}$ En el Principado de Asturias, el Jurado Provincial del Principado está adscrito a la Consejería competente en materia de ordenación del territorio y urbanismo (art. 2 del Decreto 22/2004). Lo mismo sucede en Galicia (art. 232 de la Ley 9/2002, de 30 de diciembre, de Ordenación Urbanística y Protección del Medio Rural en Galicia). En Madrid se adscribe a la Consejería competente en materia de ordenación urbanística (art. 240.1 de la Ley 9/2001, de 17 de julio). En el País Vasco, sin embargo, lo está al Departamento de Vivienda y Asuntos Sociales (art. 2 del Decreto 40/2002, de 12 de febrero, que aprueba la estructura orgánica y funciones del Departamento de Vivienda y Asuntos Sociales). El Jurado Regional de Valoraciones de Castilla-La Mancha
} 
En otro orden de cuestiones, el ámbito provincial que se ha conferido a las Comisiones responde a la idea de cercanía respecto del objeto de la expropiación ${ }^{10}$ y se inscribe en la tradición de los Jurados estatales ${ }^{11}$.

Por otra parte, disponen de plena autonomía funcional en el cumplimiento de sus funciones (DA 3 $3^{\mathrm{a}} .1$ LOUA y art. 3.1 del Reglamento); en consecuencia, sus actos ponen fin a la vía administrativa (DA 3‥2 LOUA). Al respecto, como es natural, hay que distinguir entre lo que la norma establece y lo que en la práctica suceda: por ejemplo, la circunstancia de que pueda actuar como ponente cualquier funcionario técnico facultativo al servicio de la Administración expropiante, según se verá más adelante, relativiza un tanto la atribución de autonomía funcional ${ }^{12}$.

Por último, se ha señalado que los órganos de este tipo realizan una función arbitral ${ }^{13}$. Acaso pueda ser así respecto de los Jurados Provinciales de Expropiación -al menos sobre el papel de la Ley de Expropiación Forzosa, con independencia de su funcionamiento real. Pero no parece ser ésta la intención de la Ley andaluza, que ha confiado la delicada tarea de fijación de justiprecios a órganos separados de la Administración, sí, pero con una composición alejada de los criterios de representatividad de la Ley estatal, pues se ha primado ante todo la especialización técnica de los miembros, con la finalidad -así queremos creerlo- de garantizar el acierto de las decisiones.

se adscribe a la Consejería competente en materia de Economía y Hacienda (art. 3 del Decreto 41/2003). Por su parte, la Comisión de Valoraciones de Canarias se integra en la Consejería competente en materia de Hacienda (art. 228.1 del Decreto Legislativo 1/2000, de 8 de mayo), al igual que en Extremadura el Jurado Autonómico de Valoraciones (art. 1 del Decreto 59/2003). El de Cataluña, sin embargo, sí está adscrito al Departamento de Gobernación y Relaciones Institucionales (art. 2.3 de la Ley 6/1995, en la redacción dada por la Ley 31/2002).

${ }^{10}$ En este sentido, pero respecto del Jurado Provincial de Expropiación, se pronuncia F. SOSA WAGNER, 2003, p. 141.

${ }^{11}$ Por ello, E. GARCÍA DE ENTERRÍA (2001, pp. 262 y 263) ha criticado el que en Cataluña haya un Jurado Central. Sin embargo, los Tribunales han venido considerando el carácter periférico de las secciones territoriales del Jurado de Expropiación Forzosa de Cataluña, como más adelante se verá.

12 Vid. en este sentido también E. ARANA GARCÍA y J. CUESTA REVILLA, 2003, p. 392; J. R. FERNÁNDEZ TORRES, 2004, p. 628. En cualquier caso, resulta usual la referencia a la autonomía funcional de los órganos de valoración: art. 2 del Decreto 22/2004, de 11 de marzo y art. 12 del Decreto Legislativo 1/2004, de 22 de abril, del Principado de Asturias, art. 152.1 de la Ley 2/1998, de 4 de junio, de Castilla La Mancha, art. 1.2 del Decreto 59/2003, de Extremadura, art. 232.1 de la Ley 9/2002, de Galicia y art. 240.1 de la Ley de Madrid 9/2001, del Suelo.

13 Vid. v.g. F. SOSA WAGNER, 2003, pp. 139 y 142; cita la STS de 2 de enero de 1996 (AR. 356). 


\section{COMPOSICIÓN}

La DA $33^{\text {a }} .3$ de la LOUA prescribe la siguiente composición para cada una de las Comisiones Provinciales de Valoraciones:

a) Presidente: Un funcionario de la Junta de Andalucía de un Cuerpo para cuyo ingreso se requiera titulación superior. El art. 4.2 del Reglamento precisa que lo será el Secretario General de la Delegación del Gobierno de la Junta, siempre que reúna los requisitos legales; suplente será quien designe el Delegado del Gobierno con las mismas condiciones.

b) Vocales:

a. Un Letrado al servicio del Gabinete Jurídico de la Junta de Andalucía. Lo designa el Jefe del Gabinete Jurídico de la Junta de Andalucía [art. 4.3.a) del Reglamento]

b. Cuatro técnicos superiores al servicio de la Comunidad Autónoma, que serán designados en cada caso dependiendo de la naturaleza del bien objeto de la expropiación ${ }^{14}$. De ellos, dos al menos deberán prestar servicios en la Consejería competente en materia de urbanismo. Puntualiza el art. 4.3.b) del Reglamento que los Secretarios de las Comisiones, una vez calificado cada asunto, se dirigirán al titular de la Delegación Provincial de la Consejería competente en función de la naturaleza del bien o derecho objeto de la expropiación y al de la Delegación competente en materia de urbanismo para que efectúen, en el caso de que no estuvieren designados, la propuesta de los miembros que procedan en cada caso; a la vista de la propuesta, el Delegado del Gobierno de la Junta efectuará, en su caso, las correspondientes designaciones.

c. Un notario de libre designación por el Decano del Colegio Notarial correspondiente.

d. Un técnico facultativo elegido por la Federación Andaluza de Municipios y Provincias.

\footnotetext{
${ }^{14}$ Esta previsión, inspirada en la Ley estatal, vela por el acierto de las decisiones de las Comisiones (STS de 1 de octubre de 1979, AR. 3217, cit. por F. SOSA WAGNER, 2003, p. 143). La norma andaluza, sin embargo, no detalla las titulaciones de los técnicos superiores; en cualquier caso, el criterio de los Tribunales es el de declarar la nulidad del acuerdo del Jurado si se aprecia la incompetencia del vocal técnico designado, por tener distinta especialidad o por carecer de la titulación necesaria, incluso aunque el acuerdo se hubiera adoptado por unanimidad de los miembros (vid. F. SOSA WAGNER, 2003, pp. 151 ss.; vid. también F. GARCÍA GÓMEZ DE MERCADO, 2004, pp. 72 ss., con cita de sentencias de distinta orientación).
} 
e. Un técnico representante del órgano encargado del catastro. Lo designa el titular de la Dirección General del Catastro [art. 4.3.e) del Reglamento].

f. Cuando se trate de expropiaciones locales, un representante de la Entidad Local interesada. Señala el art. 4.3.f) del Reglamento que lo designa la Entidad local, aunque no especifica quién en concreto; en consecuencia, y ante la falta de previsión expresa en la Ley Reguladora de las Bases del Régimen Local, la competencia es de los Presidentes de las Corporaciones. También indica el Reglamento que la propuesta -habría que entender designación- se efectúa con la remisión del expediente a la Comisión y que no es necesario que entre el representante y la Administración Local exista relación laboral o funcionarial alguna.

c) Secretario: actúa como secretario un funcionario de la Junta de Andalucía de un Cuerpo para cuyo ingreso se requiera titulación superior. Según el art. 4.7 del Reglamento tiene voz y voto, ha de pertenecer a la Consejería de Gobernación, se considera preferente que sea licenciado en Derecho y lo designa el Delegado del Gobierno.

La designación de los vocales a los que se refieren las letras a), c), d), e) y los dos miembros de la letra b) que, como mínimo, han de ser propuestos por la Delegación Provincial de la Consejería competente en materia de urbanismo, se hace por tiempo indefinido, con indicación de las circunstancias precisas para que las comunicaciones posteriores se realicen de forma directa con los propios vocales ${ }^{15}$. Así lo dispone el art. 4.4 del Reglamento, que en este punto parece contradecir a la Disposición Adicional $3^{a} .3$ de la Ley: ésta, en efecto, no establece excepción alguna en cuanto a que la designación se efectúe en cada caso dependiendo de la naturaleza del bien objeto de la expropiación; sólo matiza que dos técnicos deberán prestar servicios en la Consejería competente en materia de urbanismo, pero ello no quiere decir que éstos sean designados por tiempo indefinido, como pretende el Reglamento ${ }^{16}$.

\footnotetext{
15 Añade el mismo apartado cuarto del art. 4 que las designaciones, así como sus posibles modificaciones, deben ser remitidas con la antelación suficiente para la correcta celebración de las sesiones y, en todo caso, dentro del plazo que señale el Secretario de la Comisión.

${ }^{16}$ En otras Comunidades Autónomas, como Cataluña (art. 3 del Decreto 202/2000), los vocales técnicos son designados en cada caso según el contenido del expediente y la titulación requerida.
} 
Como ya avancé, pueden actuar de ponentes, a los efectos de la preparación de las propuestas de acuerdo e interviniendo en las deliberaciones de las Comisiones con voz, pero sin voto, cualesquiera funcionarios técnicos facultativos al servicio de la Junta de Andalucía o de la Administración Local, según quien sea la expropiante (DA 3 $3^{\text {. }} 4$ LOUA y art. 4.6 del Reglamento). Ha de notarse que, no exigiéndose relación laboral o funcionarial entre el representante de la Entidad Local y esta misma ${ }^{17}$, resulta paradójico que sí se le exija la relación de servicio, funcionarial además, al ponente que eventualmente se quiera designar.

Las funciones del presidente, de los vocales y del secretario se recogen en los arts. 5 a 7 del Reglamento ${ }^{18}$. Para que las Comisiones queden válidamente constituidas y puedan adoptar acuerdos es necesaria la asistencia, en primera y segunda convocatoria ${ }^{19}$, del Presidente, el Secretario y cuatro Vocales, uno de los cuáles debe ser el de la letra a), otro de la letra b) y un tercero de las letras c), d) y f); si no asiste el representante de la Administración expropiante se hace constar este hecho en acta, así como el de haber sido convocado en

${ }^{17}$ Una explicación puede ser la de que no todos los municipios cuentan con técnicos a su servicio. El art. 6.4 del Decreto 22/2004, del Principado de Asturias, sale al paso de la posible dificultad de los pequeños municipios habilitando a la Entidad Local para que formule la propuesta a favor de técnicos de la Mancomunidad a la que pertenezca.

${ }^{18}$ Las del presidente son: a) Ostentar la representación de la Comisión; b) Acordar la convocatoria de las sesiones ordinarias y extraordinarias y la fijación del orden del día, teniendo en cuenta, en su caso, las peticiones de los demás miembros formuladas con la suficiente antelación; c) Presidir las sesiones, moderar el desarrollo de los debates y suspenderlos por causas justificadas; d) Dirimir con su voto los empates, a efectos de adoptar los acuerdos; e) Asegurar el cumplimiento de las leyes; f) Visar las actas y certificaciones de los acuerdos de la Comisión Provincial de Valoraciones; g) Ejercer cuantas otras funciones sean inherentes a su condición de Presidente y aquellas otras establecidas en el Reglamento. Las de los vocales son: a) Participar en los debates de las sesiones; b) Ejercer su derecho al voto y formular su voto particular, así como expresar el sentido de su voto y los motivos que lo justifican; c) Formular ruegos y preguntas; d) Obtener la información precisa para cumplir sus funciones; e) Cuantas otras funciones sean inherentes a su condición y aquellas otras establecidas en el Reglamento. Y las funciones del secretario son las siguientes: a) Efectuar la convocatoria de las sesiones por orden de su Presidente, así como las citaciones a los miembros del mismo; b) Tramitar las notificaciones, peticiones de datos, rectificaciones o cualquiera otra clase de escritos de los que deba tener conocimiento; c) Preparar el despacho de los asuntos, redactar y autorizar las actas de las sesiones; d) Expedir las certificaciones de las consultas, dictámenes y acuerdos aprobados; e) Cuantas otras sean inherentes y aquellas otras establecidas en el Reglamento.

${ }^{19}$ La distinción entre primera y segunda convocatoria no tiene, a mi juicio, demasiado sentido. En caso de silencio en la notificación acerca de la segunda convocatoria, se entiende que puede celebrarse transcurrida media hora desde la primera (art. 18.2 del Reglamento). 
tiempo y forma (art. 19.1 del Reglamento). Las votaciones son nominales y no se prevé la abstención (art. 19.2 del Reglamento).

Rigen las normas generales de abstención y recusación, que también vinculan al ponente que eventualmente se designe al amparo del art. 4.6 (art. 8 del Reglamento). En mi opinión estas normas, y en particular las causas, han de ser interpretadas en el contexto de la función que cumplen las Comisiones Provinciales de Valoraciones ${ }^{20}$. Así, no parece que puedan esgrimirse las causas d) y e) para apartar de la Comisión a los vocales o ponente designados por la Administración ${ }^{21}$, máxime cuando se viene admitiendo que la Administración pueda designar como vocal técnico al que ha redactado la hoja de aprecio o a los que han elaborado informes sobre la valoración de los bienes ex$\operatorname{propiados}^{22}$.

${ }^{20}$ Nótese que el Reglamento de la Ley de Expropiación Forzosa, art. 32, especifica las causas de abstención. Aunque ello puede explicarse por la circunstancia de ser el Reglamento anterior a la Ley de Procedimiento Administrativo de 1958, cabe también considerar que la norma recoge conscientemente las especialidades de esta materia. El art. 10 del Decreto del País Vasco 244/1988, por su parte, menciona en particular varias causas de abstención en términos parecidos al Reglamento de la Ley estatal. A su vez, sigue esta línea el art. 6.1 del Decreto de Cataluña 202/2000, si bien invoca de modo genérico (y a mi juicio innecesario) "los supuestos de abstención y recusación previstos por la normativa general del procedimiento administrativo".

${ }^{21}$ M. CALVO CHARRO, en cambio, postula la aplicación de las causas de abstención y recusación contenidas en la Ley 30/1992 al funcionario técnico del Jurado estatal (1993, pp. 347 ss.); como ya he expuesto en mi trabajo "Los órganos autonómicos ...", esta postura conduce a plantear, en términos generales, la imposibilidad de que los órganos estén servidos por personal dependiente de la Administración, para evitar su parcialidad, lo que no tiene mucho sentido. La funcionalidad de las causas de abstención y recusación, obviamente, es muy diferente. No comparte tampoco el planteamiento de la autora citada F. GARCÍA GÓMEZ DE MERCADO, 2004, pp. 70 ss. En cambio, J. I. GARCÍA CAMPÁ y J. LLIDÓ SILVESTRE (1995, p. 632) critican el restringido régimen de recusación de la LEF:

${ }^{22}$ Vid. M. CALVO CHARRO, 1993, pp. 346 ss. y F. SOSA WAGNER, 2003, pp. 146 y 162 (con cita de jurisprudencia, se refieren a los Jurados Provinciales de Expropiación). SOSA apunta que en cualquier caso es la propia Ley la que integra en el órgano de valoración a un vocal que defienda la posición de la Administración, amén de que, en otro caso, bastaría con que el informe, hecho por quien haya formulado la hoja de aprecio, lo firmara otro funcionario. Estas consideraciones pueden hacerse extensivas al ponente que en su caso se designe.

No obstante, el art. 12.4 del Decreto Legislativo 1/2004, de Asturias, excluye que el ponente pueda ser el autor de la hoja de aprecio de la Administración y el art. 9.2 del Decreto 22/2004 establece como causas de abstención el haber participado en la formulación de la hoja de aprecio de la Administración expropiante o el haber intervenido de cualquier otra forma en el expediente de expropiación. La normativa de Extremadura, por otra parte, tras declarar el sometimiento de los miembros del Jurado a la normativa sobre incompatibilidades, especifica sólo que no podrán conocer de asuntos en los que hayan intervenido por razón del cargo que ocupan (art. 3 del Decreto 59/2003). 
En cualquier caso, la composición de las Comisiones es, como se aprecia, eminentemente técnica y especializada, muy distinta además de la que recoge la Ley de Expropiación Forzosa para el Jurado Provincial de Expropiación ${ }^{23}$, que optó por un modelo de representación de los intereses contrapuestos ${ }^{24}$, al menos en teoría ${ }^{25}$. No se contempla la presencia del Magistrado ${ }^{26}$, a dife-

${ }^{23}$ Según el art. 32 LEF, lo preside un Magistrado (Juez de Primera Instancia en Ceuta y Melilla) y lo integran además cuatro vocales: a) Un Abogado del Estado; b) Un funcionario técnico, variable según la naturaleza del bien: Ingeniero Agrónomo, Ingeniero de Caminos, Ingeniero de Montes, Ingeniero de Minas, Arquitecto o Profesor mercantil; el art. 32.1 REF menciona también el Ingeniero Industrial; en los demás casos, el funcionario técnico más idóneo (art. 32.1 LEF y art. 32.1 REF); en las expropiaciones por razón del urbanismo o llevadas a cabo por las Corporaciones Locales, este funcionario es designado por la Corporación interesada (art. 85 LEF); en las expropiaciones por necesidades militares es un técnico militar (art. $100 \mathrm{LEF}$ ); c) un representante de la Cámara Agraria Provincial, Cámara de la Propiedad Urbana, Cámara de Comercio, Industria y Navegación, Colegio Profesional u Organización Empresarial (RD 3112/1978, de 7 de diciembre); d) un Notario de libre designación por el Decano del Colegio Notarial correspondiente. Actúa como Secretario un funcionario del Cuerpo Técnico-Administrativo designado por el Gobernador (art. 33.4 LEF).

${ }^{24}$ Así lo explica la Exposición de Motivos: "El artículo 32 fija la composición del Jurado, atribuyendo su presidencia a un Magistrado, con lo que garantiza la objetividad de visión y el rigor judicial del procedimiento y asegura la representación de los intereses financieros y fiscales de la Administración y patrimoniales de la propiedad privada, así como los de índole técnica, incluyendo finalmente a un Notario, en atención a su conocimiento de las transacciones y a la independencia de su función pública".

${ }^{25}$ Se ha criticado -F. SOSA WAGNER, 2003, p. 144, se hace eco de ello- "la falta de una directa representación del expropiado, cuyos intereses no son defendidos ni por el notario ni por el representante de las corporaciones o asociaciones mercantiles". El autor citado (ibidem) ha subrayado también que sólo cuenta con dos vocales la Administración estatal, no la Administración autónomica ni la local; el beneficiario, por otra parte, no dispone de ningún representante. Vid. también E. GARCÍA DE ENTERRÍA, 2001, pp. 260 y 261.

26 Sí figuraba en la Ley de Cataluña 6/1995, de 28 de junio (art. 2), en la Ley de Madrid 9/1995, de 28 de marzo, en las Leyes Forales 7/1989, de 8 de junio (Disposición Adicional tercera) y 10/1994, de 4 de julio (Disposición Adicional décima), en la Ley de Castilla-La Mancha 2/1998 (art. 152) y en la Ley canaria 9/1999. La primera fue modificada por el art. 78 de la Ley 31/2002, de 30 de diciembre, en virtud del cuál el Presidente es un jurista de reconocido prestigio, con más de siete años de ejercicio profesional. La segunda lo fue por el art. 10 de la Ley 24/1999, de 27 de diciembre, de modo que el Presidente es un jurista de reconocida competencia con más de diez años de experiencia profesional e independiente de las Administraciones con competencias expropiatorias en la región. A su vez, la Ley Foral 35/2002, de 20 de diciembre, ha prescindido de la composición prevista en las Leyes Forales 7/1989 y 10/1994, si bien sólo señala que el Jurado estará formado por "cinco miembros, que serán designados por el Gobierno de Navarra entre personas con experiencia profesional en valoraciones inmobiliarias, uno de los cuales será su Presidente". En Castilla-La Mancha, preside el Jurado un jurista de reconocido presti- 
rencia de la Ley estatal, pero en consonancia con lo postulado por el Consejo General del Poder Judicial ${ }^{27}$, el criterio sentado por el Tribunal Constitucional ${ }^{28}$ y la línea seguida por la normativa más reciente de las Comunidades Autónomas ${ }^{29}$. Sí se mantiene, no obstante, la pertenencia al órgano del notario, aunque se ha puesto de manifiesto que suele eludir compromisos y hasta es común que no asista a las sesiones ${ }^{30}$. Por otra parte, resulta muy llamativo el fortalecimiento de la figura del Secretario, que dispone de voz y voto ${ }^{31} \mathrm{y}$, co-

gio y más de diez años de experiencia (redacción debida a la Leyl/2003, de 17 de enero). En Canarias, la Ley 2/2002 situó en la presidencia al Director General del Servicio Jurídico del Gobierno de Canarias.

Salvo error por mi parte, los Jurados Territoriales de Expropiación Forzosa del País Vasco siguen estando presididos por Magistrados, al menos formalmente (art. 2 de la Ley 8/1987, de 20 de noviembre, de Creación de los Jurados Territoriales de Expropiación Forzosa y art. 2 del Decreto 244/1988, de 20 de septiembre, que aprueba el Reglamento de Funcionamiento de los Jurados Territoriales de Expropiación Forzosa).

27 "Problemas que se suscitan a propósito del ejercicio por los Presidentes de los Tribunales Superiores de Justicia de las competencias previstas en los arts. 112 y ss. del Reglamento Hipotecario y de la participación de los Magistrados en los Jurados de Expropiación, analizando la conveniencia de mantener las referidas competencias o de sugerir las modificaciones legales pertinentes para su desaparición”, Informe aprobado por el Pleno del Consejo General del Poder Judicial en su reunión del día 19 de junio de 1998 (1/98), Estudios, informes y dictámenes, Tomo II, Madrid, 1999, pp. 887 ss. Sobre el mismo vid. C. PICO LORENZO, 2001, pp. 158 ss.

El Consejo informó negativamente la participación de Magistrados en los Jurados de Expropiación por considerar que ello "podría afectar al funcionamiento de los Juzgados y Tribunales, así como al estatuto jurídico de los Jueces y Magistrados, ámbito comprendido en la reserva constitucional de ley orgánica (art. 122.1 CE)"; asimismo porque los cometidos de los Jurados se compadecen mal con el régimen de incompatibilidades de Jueces y Magistrados y "podrían incidir en los asuntos que han de ser conocidos por los órganos jurisdiccionales de su propio ámbito territorial, agotando la vía administrativa previa a la jurisdiccional”; por último, porque, "al margen de la implicación específica del Magistrado en cuestiones que pudieran requerir su posterior intervención jurisdiccional, la participación judicial ... podría afectar a las exigencias estructurales de independencia que son predicables de la potestad jurisdiccional y, consecuentemente, a la imagen del Poder Judicial ante el justiciable y el conjunto de la sociedad" (vid. pp. 906 y 907).

${ }^{28}$ Vid. la nota núm. 6.

29 Vid. la nota núm. 26.

30 Vid. E. GARCÍA DE ENTERRÍA, 2001, p. 260. Vid. también J. I. GARCÍA CAMPÁ y J. LLIDÓ SILVESTRE, 1995, p. 631.

31 No disponen de voto, por determinación expresa de la normativa, los secretarios de los órganos de valoración de Cataluña (art. 3.2 de la Ley 6/1995), Castilla-La Mancha (art. 152 de la Ley 2/1998), Castilla y León (art. 420 del Reglamento de Urbanismo) y Extremadura (art. 153 de la Ley 15/2001, de 14 de diciembre). 
mo veremos más adelante, califica en primera instancia el expediente como expropiatorio o no y elabora la propuesta de acuerdo.

Con todo, el aspecto más relevante de las Comisiones es el de que formalmente no reflejan ningún equilibrio en su composición ${ }^{32}$, amén del incremento del número de miembros. Respecto de esto último, no sólo acrece el número de sus componentes, lo cual ciertamente puede resultar ventajoso ${ }^{33}$, sino que incluso cuando se trata de una expropiación local, el representante de esta Administración se suma a los miembros ordinarios ${ }^{34}$. Debe notarse, además, la eventual presencia de funcionarios técnicos facultativos, al servicio de la Junta o de la Administración local, según los casos, que aunque no disponen de voz pueden preparar las ponencias e intervenir en las deliberaciones ${ }^{35}$.

\footnotetext{
${ }^{32} \mathrm{~A}$ diferencia de otros órganos de valoración autonómicos, como el Jurado Provincial del Principado de Asturias, cuyo Presidente es un jurista de acreditada competencia en las materias propias de la actuación del Jurado, con más de diez años de experiencia profesional, designado por acuerdo del Consejo de Gobierno; entre sus vocales cuenta además con cuatro profesionales libres colegiados que tengan acreditada competencia en las materias propias del ámbito competencial del Jurado, en representación de los Colegios Oficiales de Arquitectos o Ingenieros Superiores, Cámaras Oficiales, organizaciones empresariales de mayor representatividad en el sector y asociaciones representativas de la propiedad, a propuesta de las respectivas entidades, dependiendo de la naturaleza del bien o derecho objeto de la expropiación (arts. 5 y 6 del Decreto 22/2004). En Cataluña (art. 2.2 de la Ley 6/1995, en la redacción dada por la Ley 31/2002, de 30 de diciembre) y País Vasco (art. 2 de la Ley 8/1987, de 20 de noviembre) se sigue, como se ha señalado, el modelo estatal, con alguna matización (en Cataluña, si la índole de lo expropiado lo exige, se puede escoger como vocal a más de un titulado, de modo que se altera la supuesta regla de la paridad; cfr. el art. 3.4 del Decreto 202/2000).
}

No parecen guardar el equilibrio a que se alude el Jurado Territorial de Expropiación de la Comunidad Autónoma de Madrid (vid. el art. 240.4 de la Ley 9/2001), el Jurado Autonómico de Valoraciones de Extremadura (vid. el art. 153 de la Ley 15/2001), la Comisión de Valoraciones de Canarias (vid. el art. 228 del Decreto-Legislativo 1/2000, de 8 de mayo), el Jurado Regional de Valoraciones de Castilla-La Mancha (vid. el art. 152 de la Ley 2/1998, de 4 de junio), las Comisiones Territoriales de Valoración de Castilla y León (vid. el art. 420 del Decreto 22/2004), ni el Jurado de Expropiación de Galicia (art. 232.3 de la Ley 9/2002, de 30 de diciembre).

${ }^{33}$ F. SOSA WAGNER (2003, p. 159) ha puesto de manifiesto que el pequeño número de miembros del Jurado estatal, que facilita la agilidad de su funcionamiento, puede entorpecer o dificultar la actuación, ante una reiterada inasistencia o declaración de incompatibilidad.

${ }^{34} \mathrm{El}$ art. 85.2 de la Ley estatal, al regular las expropiaciones locales, dispone que el funcionario técnico será designado por la Corporación local. La jurisprudencia ha extendido esta previsión al supuesto de las Comunidades Autónomas (vid. F. SOSA WAGNER, 2003, p. 146).

${ }^{35}$ Como ha subrayado F. SOSA WAGNER (2003, p. 144), lo relevante y lo que influye en la decisión de los demás miembros del órgano colegiado es la opinión que formula el técnico, no su voto. 
La ruptura del equilibrio formal en la composición de los órganos de valoración autonómicos ha sido ampliamente criticada por la doctrina ${ }^{36}$. Y, desde luego, las Comisiones Provinciales de Valoración andaluzas no han escapado de esta tendencia mayoritaria ${ }^{37}$. En mi opinión, debe considerarse que el desequilibrio se produce, precisamente, por la incorporación al órgano de técnicos especialistas, cuyos conocimientos y experiencias pueden coadyuvar de modo decisivo a la fijación de justiprecios "justos"; en este sentido, el órgano de composición técnica tiene ciertamente a su favor la mayor probabilidad de acierto de sus decisiones. No comparto, por consiguiente, tales opiniones críticas, o al menos no en su integridad. Como ya he expresado con anteriori$\mathrm{dad}^{38}$, la solución óptima es, naturalmente, conciliar las dos opciones que como disyuntiva parecen ofrecerse: un órgano formado por miembros expertos en la materia y que, además, sea representativo de los intereses de los expropiados; algo a lo que, por otra parte, aspiró la LEF sin conseguirlo. En la encrucijada de las dos opciones, me parece más eficaz, en los términos que vengo considerando, un tipo de órgano en el que quede asegurado el conocimiento de la materia y la especialización técnica de sus miembros, pero formados por funcionarios de carrera, acaso dedicados con exclusividad a este menester ${ }^{39}$, cuya actuación, como ha recordado SOSA WAGNER al tratar del

Ha de notarse que en la normativa asturiana la intervención del ponente se limita a expedientes concretos cuya complejidad o especialidad así lo requiera (art. 8 del Decreto 22/2004).

36 Vid. T. R. FERNÁNDEZ RODRÍGUEZ, 2000, p. 101 ss. E. GARCÍA DE ENTERRÍA, 2001, pp. 263 y 264. M. GARCÉS SANAGUSTÍN, 2003, pp. 191 ss. y L. F. PRIETO GONZÁLEZ, 2003, p. 261.

\footnotetext{
${ }^{37}$ En la obra colectiva Ley de Ordenación Urbanística de Andalucía: estudio preliminar, comentarios a su articulado y formularios, se ha señalado que su composición "no es paritaria ni arbitral, produciéndose en este extremo un retroceso respecto de la LEF ... este órgano no tiene acreditada la especialización que gratuitamente le otorga la LOUA. Además, su composición dista mucho de ser independiente e imparcial, por lo que, salvo que con la legitimación del ejercicio se afiance, la garantía del expropiado de que su justiprecio se fije en vía administrativa por un órgano imparcial e independiente ha quedado, según nuestro parecer, seriamente devaluada" (p. 38). Más adelante se critica que la Ley reduzca la representación de los intereses privados al Notario; también se señala que "al no participar un miembro de la carrera judicial rompe definitivamente la igualdad de armas entre el expropiado y la Administración" (p. 39). Vid. también J. R. FERNÁNDEZ TORRES, 2004, pp. 627 y 628.

38 "Los órganos autonómicos ..", cit.

${ }^{39}$ El Defensor del Pueblo ha abogado porque se dote de permanencia y profesionalidad a los Jurados; la gestión de quejas recibidas ha puesto de manifiesto que un inconveniente para el normal desarrollo de las sesiones del Jurado es el de ser la función de miembro del mismo una actividad complementaria de otra principal. Vid. E. MÚGICA HERZOG, 2003, pp. 28, 34, 35 y 37.
} 
Jurado estatal, "siempre debe inspirarse por los principios de objetividad e imparcialidad, así como la defensa de los intereses públicos (art. $103 \mathrm{CE}){ }^{40}$. Si a ello se le añadiese una regulación de los criterios de valoración que propiciara el automatismo en la determinación de justiprecios y la reducción de la discrecionalidad, en la línea apuntada por CANCER MINCHOT ${ }^{41}$ y GARCÉS SANAGUSTÍN ${ }^{42}$, las sospechas de parcialidad quedarían más que atenuadas.

\section{FUNCIONES}

Las Comisiones Provinciales de Valoraciones conocen de los procedimientos de determinación del justiprecio de todas las expropiaciones forzosas cuando la Administración expropiante es la de la Comunidad Autónoma de Andalucía o cualquiera de las Entidades Locales de su territorio que, obviamente, tenga atribuida la potestad (DA 3 ${ }^{3} .2$ LOUA y art. 2.1 del Reglamento). Aclara el art. 162 LOUA que también intervienen en el procedimiento de tasación conjunta ${ }^{43}$.

40 2003, p. 144. Más adelante propugna, respecto del Jurado estatal, "la configuración de un órgano permanente, al que estén adscritos o presten servicios personal técnico cualificado, que puedan ofrecer una objetiva valoración de los bienes expropiados"; añade que "no es necesario que participen otros funcionarios o profesionales, que no aportan criterios ni opiniones económicas, como el magistrado, el abogado del Estado o el notario, y que sin embargo, su participación exige que se espacien las reuniones, retrasando la solución de los expedientes" (2003, p. 178).

M. CALVO CHARRO, en cambio, duda de la imparcialidad del vocal técnico del Jurado estatal por ser, precisamente, un funcionario (1993, pp. 344 y 345). Como sabemos, la autora postula la aplicación de las causas de abstención y recusación contenidas en la Ley 30/1992 al funcionario técnico del Jurado (pp. 347 ss.), postura ésta que no comparto.

41 2003, pp. 123 y 124.

42 2003, pp. 180 y 181.

${ }^{43}$ Una precisión análoga se recoge, como es natural, en las normas que disciplinan otros órganos de valoración autonómicos: art. 187 del Decreto Legislativo del Principado de Asturias 1/2004 y art. 3 del Decreto, también del Principado, 22/2004; arts. 107 y 140 de la Ley catalana 2/2002, de 14 de marzo, de Urbanismo; art. 2.2 del Decreto de Castilla-La Mancha 41/2003; art. 2 del Decreto de Madrid 71/1997; art. 143 de la Ley de Galicia 9/2002, de 30 de diciembre, de Ordenación Urbanística y protección del medio rural; art. 130 del Decreto Legislativo de Canarias $1 / 2000$, de 8 de mayo.

En Galicia se prevé expresamente su intervención cuando hay discrepancia en el proyecto de compensación de la junta de compensación (art. 157 Ley 9/2002, de 30 de diciembre, de Ordenación Urbanística y Protección del Medio Rural). 
No actúan, por tanto, cuando la Administración expropiante es la Administración General del Estado, a diferencia de lo que dispone la normativa del País Vasco ${ }^{44}$, de Cataluña ${ }^{45}$ y de Navarra ${ }^{46}$.

Tampoco actúan en materia de responsabilidad patrimonial, como han previsto otras Comunidades Autónomas. Así, el Jurado Regional de Valoraciones de Castilla-La Mancha tiene competencias de índole consultiva en materia de responsabilidad, cuando ésta proceda por razón de la ordenación territorial y urbanística ${ }^{47}$. También la Comisión de Valoraciones de Canarias asume funciones en materia de responsabilidad en los ámbitos de la ordenación territorial y urbanística ${ }^{48}$, siempre que, con carácter previo, dicha responsabilidad haya sido declarada y no cuantificada en vía administrativa o judicial o se haya emitido informe en tal sentido por el Consejo Consultivo de Canarias; tal facultad se hace extensiva a las valoraciones procedentes de indemnizaciones imputables a las restantes Administraciones Públicas canarias, siempre que la soliciten expresamente. El art. 139 de la Ley 5/1999, de 8 de abril, de Urbanismo, recoge la competencia de las Comisiones Territoriales de Valoración de Castilla y León para la emisión de informes en razón de su especialidad, así como en cuanto a los supuestos indemnizatorios previstos en la Ley, y para ejercer otras funciones que se les encomienden reglamentariamente; según el art. 419.b) del Reglamento de Urbanismo, le corresponde "valorar las indemnizaciones por responsabilidad patrimonial en materia de urbanismo y ordenación de territorio de la Administración de la Comunidad Autónoma, cuando dicha responsabilidad haya sido previamente reconocida pero no haya sido cuantificada en vía judicial o administrativa. Esta función puede ejercerse

\footnotetext{
${ }^{44}$ Disposición Adicional de la Ley 8/1987, de 20 de noviembre, de creación de los Jurados Territoriales de Expropiación Forzosa, que supedita esta posibilidad al acuerdo con la Administración del Estado.

${ }^{45}$ Disposición adicional segunda de la Ley 6/1995, que no obstante se remite a lo que disponga la legislación aplicable.

${ }^{46}$ Art. 126 de la Ley Foral 35/2002, de 20 de diciembre, de Ordenación del Territorio y Urbanismo, que exige acuerdo con la Administración General del Estado (igualmente figuraba esta previsión en la Disposición Adicional tercera de la Ley Foral 7/1989, de 8 de junio, de Medidas de Intervención en suelo y Viviendas, así como en la Disposición Adicional décima de la Ley Foral 10/1994, de 4 de julio, de Ordenación del Territorio y Urbanismo).

47 Art. 152.1 de la Ley 2/1998, de 4 de junio, de Ordenación del Territorio y Urbanismo. Art. 2.3 del Decreto 41/2003.

${ }^{48}$ Art. 228 del Decreto Legislativo 1/2000, de 8 de mayo.
} 
también respecto de las indemnizaciones de las Diputaciones Provinciales, los Municipios y las demás entidades locales de Castilla y León, previa solicitud de cualquiera de dichas Administraciones públicas, sea para un expediente concreto o con carácter general”. El Jurado Territorial de Expropiación Forzosa de Madrid no realiza en la actualidad funciones en el ámbito de la responsabilidad $^{49}$.

En el ejercicio de su función, las Comisiones han de velar por la aplicación homogénea de los criterios de valoración en los procedimientos de tasación de bienes y derechos que les sean sometidos (art. 2.2 del Reglamento). Sin embargo, no se indica de qué modo puede hacerse efectiva esta aspiración a nivel regional, a diferencia, de nuevo, de lo que se prevé en otras Comunidades, como País Vasco y Cataluña ${ }^{50}$, que regulan las denominadas Comisiones Técnicas de Valoraciones ${ }^{51}$. En Cataluña se prevé además que los vocales

\footnotetext{
${ }^{49} \mathrm{El}$ art. 102 de la Ley de la Comunidad de Madrid 9/1995, de 28 de marzo, de Medidas de Política Territorial, Suelo y Urbanismo, caracterizó al Jurado como el órgano de la Administración de la Comunidad de Madrid especializado en materia de expropiación forzosa y de responsabilidad patrimonial. En este último ámbito se configuraba como superior órgano consultivo de la Comunidad y de los Municipios si así lo solicitaban. La Exposición de Motivos de la Ley valoraba esta opción como "una positiva unificación de criterio en materia de garantías patrimoniales de los ciudadanos frente a la acción pública”. Sin embargo, el Decreto 71/1997, de 12 de junio, que aprueba el Reglamento de Organización y Funcionamiento del Jurado Territorial, no alude a esta faceta del Jurado, que también se omite en la nueva Ley del Suelo 9/2001, de 17 de julio.
}

${ }^{50}$ Es del art. 1.1 del Decreto 202/2000, de esta Comunidad, de donde se toma la referencia al establecimiento de criterios homogéneos en los procedimientos de valoración.

${ }^{51}$ El art. 6 de la Ley del País Vasco 8/1987, de 20 de noviembre, dispone su constitución de entre los miembros de los Jurados Territoriales de Expropiación Forzosa, con las siguientes funciones: a) Analizar las principales cuestiones que se planteen en aplicación de los criterios legales para la valoración de los bienes y derechos objeto de expropiación; b) Recoger las observaciones necesarias para el funcionamiento de las distintas Administraciones Públicas en lo referente a la aplicación de las legislaciones que influyen afectan y en su caso definen las valoraciones de los bienes y derechos; c) Contrastar y formar criterios uniformes para realizar la tasación de bienes y derechos; d) Sugerir disposiciones generales y medidas a adoptar para el mejor funcionamiento de la Administración en lo referente al apartado b) anteriormente indicado. La Comisión debe elaborar anualmente un informe, que debe presentarse a las distintas Administraciones que hayan actuado como órganos expropiantes dentro del período a que se refiere el informe en el que deben recogerse de forma sintetizada y ordenada los problemas, observaciones, criterios y sugerencias que constituyen las materias objeto de los trabajos de la Comisión. La Comisión Técnica de Valoraciones puede solicitar la inclusión entre sus miembros de expertos en las materias relacionadas con la valoración de bienes y derechos.

El art. 6 de la Ley de Cataluña 6/1995 contiene una regulación muy parecida. Además, el art. 11.3 del Decreto de Cataluña 202/2000 prevé que por motivos de complejidad o unificación de criterios, el Jurado remita el expediente a la Comisión Técnica de Valoraciones a fin de que emi- 
de las diferentes Secciones del Jurado se puedan reunir para tratar conjuntamente el estudio y debate de asuntos de interés común, a propuesta de los presidentes de las Secciones; también se indica que los vocales permanentes de las Secciones se pueden reunir válidamente a fin de adoptar acuerdos que no sean resoluciones sobre el justiprecio (art. 2.3 y 4 del Decreto 202/2000).

\section{PROCEDIMIENTO}

El Reglamento contempla el procedimiento ante las Comisiones Provinciales como si de un procedimiento autónomo se tratase, en vez de considerarlo como una pieza del procedimiento más amplio de expropiación forzosa. De este modo, regula el inicio del mismo y, sobre todo, prevé su terminación por silencio administrativo negativo, lo que, según se verá más adelante, no parece correcto ${ }^{52}$.

El procedimiento ante las Comisiones se inicia mediante la remisión a las mismas del expediente del justiprecio por la Administración expropiante, en el caso de que el titular del bien o del derecho objeto de expropiación no haya aceptado el precio fundado ofrecido por la Administración ${ }^{53}$. También puede efectuar la remisión el propio titular, en los supuestos en que proceda la iniciación del expediente por ministerio de la Ley (art. 11.1 del Reglamento ${ }^{54}$. Actúa como registro de entrada y salida de documentos el registro ge-

ta informe. El art. 14.1 de este mismo Decreto, más taxativo, señala que son funciones de la Comisión, entre otras, las siguientes: formar criterios uniformes en materia de tasación de bienes y derechos; establecer criterios generales uniformes sobre valoración de los bienes y derechos y modelos uniformes para facilitar la tarea de los vocales técnicos del Jurado; recoger observaciones y sugerir propuestas para la aplicación de las legislaciones que afecten y, si procede, definir las valoraciones de los bienes y derechos, incluida la adopción de disposiciones de carácter general; establecer criterios de valoración de bienes y derechos relacionados con las nuevas tecnologías. Y el apartado 3 del citado art. 14 añade que a fin de garantizar la unidad de criterios en su actuación, las secciones del Jurado de Expropiación y la Comisión Técnica de Valoraciones están sujetas a los principios de información recíproca, coordinación y colaboración que establece la legislación sobre procedimiento administrativo.

${ }^{52}$ La Ley también parece participar de esta consideración, pues señala que las Comisiones "actuarán con competencia resolutoria definitiva" (DA $\left.3^{3} \cdot 2\right)$.

${ }^{53} \mathrm{Si}$ existe un beneficiario de la expropiación debe, como señala F. SOSA WAGNER (2003, p. 94), comunicar a la Administración el fracaso del mutuo acuerdo y la necesidad de abrir el procedimiento para fijar el justiprecio.

54 Vid. los arts. 63 (reservas de aprovechamiento) y 140 LOUA (ocupación y expropiación de los terrenos destinados a dotaciones). 
neral de la correspondiente Delegación del Gobierno (art. 11.2 del Reglamento).

El Decreto no contempla qué sucede cuando la Administración no remite el expediente al Jurado. La vigente LJCA permite considerar que estamos ante un supuesto de inactividad de la Administración ${ }^{55}$; con anterioridad, el Tribunal Supremo mantuvo que "la petición de prosecución y finalización de expediente, en caso de no ser resuelta por la administración, puede ser sometida a los Tribunales con arreglo a las normas que disciplinan el silencio administrativo" ${ }^{56}$. Otra solución, en consonancia con lo previsto para las expropiaciones por ministerio de la ley, sería la de considerar al expropiado habilitado para remitir directamente su hoja de aprecio a la Comisión.

El expediente debe contener como mínimo los siguientes documentos: a) Descripción física, gráfica y jurídica del bien o derecho objeto de expropiación; b) Hoja de aprecio, ofertas o condiciones propuestas por el expropiado, en la que se exprese una justificación sucinta de las valoraciones realizadas o, en su defecto, el requerimiento formulado por la Administración expropiante a fin de que lo aporte; c) Hoja de aprecio de la Administración expropiante (art. 13 del Reglamento). Recordemos que si se trata de una expropiación local, la Entidad local debe proceder a la propuesta de un técnico [art. 4.3.f) del Reglamento]. No se exige, a diferencia del art. 29 REF, un extracto de las actuaciones seguidas para lograr un mutuo acuerdo.

Conviene llamar la atención acerca del distinto tratamiento que se otorga a la hoja de aprecio del expropiado y a la de la Administración, pues de ésta no se especifica nada y de la de aquél se indica que debe expresar "una justificación sucinta de las valoraciones realizadas" ${ }^{\text {" }}$. Esta precisión es discutible y de hecho debe considerarse inoperante, pues como se ha destacado, "cuantos más argumentos amparen un criterio valorativo mayor razonamiento se exigirá del Jurado Provincial para rechazar la estimación" ${ }^{8}$.

\footnotetext{
${ }^{55}$ Aunque, como se ha señalado respecto de la omisión de la hoja de aprecio de la Administración, "la sentencia favorable será una verdadera conquista pírrica" (F. SOSA WAGNER, 2003, p. 130).

${ }^{56}$ SS. de 21 de febrero y 18 de junio de 1997 (AR. 991 y 4709), cit. por F. SOSA WAGNER (2003, p. 96).

${ }^{57}$ La norma andaluza sigue el art. 8 del Decreto catalán 202/2000, de 13 de junio.

${ }^{58}$ F. SOSA WAGNER, 2003, p. 114.
} 
Por otra parte, no se detalla qué sucede cuando se remite a la Comisión sólo el requerimiento de la Administración para que se aporte la hoja de aprecio y la propia hoja de la Administración. Debe considerarse, con SOSA WAGNER ${ }^{59}$, que en este caso la Comisión recabará la hoja de aprecio del expropiado y, en última instancia, fijará el justiprecio con los datos obrantes en el expediente incompleto, sin quedar vinculada por la hoja de aprecio de la Administración, que sólo opera como límite mínimo de la indemnización.

Una vez recibido el expediente administrativo, el secretario debe comprobar que contiene todos los documentos preceptivos y calificar el expediente, determinando si es o no expropiatorio; dispone de siete días al efecto (art. 14.1 del Reglamento). El plazo para subsanar la ausencia de algún documento es de diez días (art. 14.2 del Reglamento). Recordemos que una vez calificado el expediente, debe el secretario dirigirse al titular de la Delegación Provincial de la Consejería competente en función de la naturaleza del bien o derecho objeto de la expropiación y al de la Delegación competente en materia de urbanismo para que efectúen, en el caso de que no estuvieren designados, la propuesta de los miembros que procedan en cada caso; a la vista de la propuesta, el Delegado del Gobierno de la Junta efectúa, en su caso, las correspondientes designaciones [art. 4.3.b) del Reglamento].

Si el secretario considera que el expediente no tiene carácter expropiatorio, en contra de la determinación de la Administración expropiante o del titular del bien o derecho, ha de abrir un trámite de vista a los interesados, por un plazo de diez días, para que puedan formular alegaciones; a continuación debe elaborar una propuesta de resolución de esta incidencia para que la resuelva la Comisión en la siguiente sesión ordinaria (art. 14.3 del Reglamento). Si se resuelve la naturaleza no expropiatoria, el secretario devolverá el expediente a la Administración remitente a los efectos correspondientes (art. $14.4 \mathrm{del}$ Reglamento).

Esta previsión, desconocida en la legislación estatal e inspirada en la regulación catalana ${ }^{60}$, supone una distorsión de la genuina función de la Comi-

592003 , pp. 123 y 173 y 174.

${ }^{60}$ Art. 9 del Decreto 202/2000, de 13 de junio, que aprueba el Reglamento del Jurado de Expropiación de Cataluña. 
sión $^{61}$. Sin embargo, puede estar justificada en los casos en que es el expropiado el que insta la fijación del justiprecio.

Una vez que se comprueba que el expediente contiene los documentos que enumera el art. 13, así como su naturaleza expropiatoria, el secretario elabora la propuesta de acuerdo de valoración basándose en los informes obrantes en el expediente, en el plazo máximo de veinte días desde la calificación del expediente (art. 15.1 del Reglamento); a tal efecto, puede recabar los informes técnicos que considere necesarios (art. 15.2) ${ }^{62}$. Aun cuando en esta sede no lo mencione el Reglamento, puede acordar la práctica de pruebas ${ }^{63}$; también contempla el art. 12.2 la obtención de otras Administraciones de informaciones determinantes para la valoración y la realización de inspecciones sobre el terreno.

La propuesta debe expresar sus antecedentes, con descripción del bien o derecho objeto de expropiación y con exposición motivada de la normativa

${ }^{61}$ Y de lo que ha sido la nota característica del Jurado Provincial de Expropiación, esto es, el soslayamiento de valoraciones jurídicas (vid. A. GUILLÉN ZANÓN, 1990, p. 280). Como también expresa F. SOSA WAGNER (2003, p. 168), recogiendo la jurisprudencia sobre la materia, la función del Jurado es "«exclusivamente tasadora» y ... por ello están fuera de su ámbito de decisión las cuestiones de carácter jurídico, como el derecho que se tenga o no a percibir una indemnización. Su competencia no es de «interpretación y definición del derecho»" (cita las SSTS de 12 de marzo de 1983, AR 5709 de 1984, y 26 de mayo de 1987, AR. 9256); vid.. también la p. 145 ("el Jurado no puede entrar en consideraciones jurídicas").

${ }^{62}$ No se especifica la procedencia de los informes técnicos. En Cataluña, el art. 11 del Decreto 202/2000 prevé que el Jurado, cuando la complejidad o especialidad del expediente lo requiera, pueda acordar la designación de una ponencia técnica para que elabore un informe; esta ponencia puede estar integrada por vocales técnicos expertos de la Comisión Técnica de Valoraciones o por profesionales inscritos en la base de datos que regula el art. 16 de la disposición. Como ya nos consta, puede también, por motivos de complejidad o unificación de criterios, remitir el expediente a la Comisión a fin de que emita informe.

En Castilla y León, el Reglamento de Urbanismo dispone que, cuando la complejidad técnica del asunto así lo requiera, el Presidente pueda recabar los informes técnicos que considere oportunos o convocar a las personas que estime conveniente para su mejor asesoramiento; éstas tendrán voz pero no voto (art. 421.2).

${ }^{63}$ F. SOSA WAGNER, 2003, p. 174. Más adelante se refiere el Reglamento a "la prueba aportada" (art. 15.4). Nótese que el art. 12.2 prevé la prórroga del plazo para fijar el justiprecio cuando se lleve a cabo una inspección sobre el terreno de los bienes o derechos a valorar; esta prueba, sin embargo, no se lleva a cabo en esta fase del procedimiento, sino una vez efectuada la propuesta y tras acordarlo así la Comisión, en la sesión en la que se reúna para adoptar el acuerdo de valoración (si bien, como es lógico, a la postre no se adopta este acuerdo, sino el de prórroga para realizar la inspección). 
aplicable, debiendo valorar la prueba aportada, en su caso, y pronunciarse sobre las alegaciones que consten en el expediente (art. 15.4 del Reglamento). Nótese, sin embargo, que no se prevé expresamente ni un trámite para presentar alegaciones con anterioridad a la propuesta ${ }^{64}$ ni la realización de pruebas.

De la propuesta de acuerdo se da audiencia, de forma simultánea y por plazo común de diez días, al sujeto expropiado ${ }^{65}$ y a la Administración expropiante (art. 15.3 del Reglamento). No se contempla la realización, como sucede en la legislación catalana, de un trámite de conciliación voluntario antes de la propuesta ${ }^{66}$, aunque sí, como se verá a continuación, el acuerdo sobre la prórroga.

A diferencia de la LEF, la normativa andaluza no menciona que la valoración de la Comisión se haya de producir "a la vista de las hojas de aprecio" (art. 34), de modo que puede plantearse si éstas operan como un límite en orden a la fijación del justiprecio: al respecto, resulta oportuno recordar que, como regla general, con muy escasas excepciones, la jurisprudencia sostiene la vinculación de los Jurados Provinciales de Expropiación, si bien con diferente amplitud ${ }^{67}$.

El acuerdo de valoración se produce una vez recibidas las alegaciones a la propuesta o transcurrido el plazo para ello (art. 16.1 del Reglamento). Se establece un plazo de tres meses para adoptar y notificar los acuerdos, a contar

${ }^{64}$ Salvo las alegaciones sobre la naturaleza expropiatoria o no del expediente.

${ }^{65}$ Hay que considerar que cualquier interesado puede participar en el procedimiento, de modo que se ha de dar audiencia a aquellos que se hayan personado. Recordemos, por otra parte, que el art. 4.1 LEF precisa que siempre que lo soliciten, acreditando su condición debidamente, se entenderán también las diligencias con los titulares de derechos reales e intereses económicos directos sobre la cosa expropiada, así como sobre los arrendatarios cuando se trate de inmuebles rústicos o urbanos; para éstos además, como se sabe, se sigue un expediente individual.

${ }^{66}$ Art. 10 del Decreto 202/2000.

${ }^{67}$ Vid. F. SOSA WAGNER, 2003, pp. 175 ss. En la normativa catalana no sólo se señala que el acuerdo se adopta "a la vista de las hojas de valoración", sino que se especifica que la propuesta "no puede empeorar la condición del expropiado en relación con la hoja de aprecio de la Administración expropiante, y ha de ser congruente con las peticiones del expropiado, en caso de que las acepte, total o parcialmente" (art. 11 del Decreto 202/2000). En Extremadura, el art. 4.4 del Decreto 59/2003 expresa también que la valoración propuesta "deberá ceñirse a los límites cuantitativos máximos y mínimos propuestos en las hojas de aprecio”. La Ley Foral 35/2002 incluye la expresión "a la vista de las hojas aprecio formuladas ..." (art. 126.5). 
desde el día siguiente a la entrada del expediente en el registro (art. 12.1 del Reglamento).

Se prevé la prórroga de ese plazo con carácter excepcional, por un mes, cuando deban obtenerse de otras Administraciones informaciones que sean determinantes para la valoración o cuando la complejidad del bien o derecho objeto del expediente aconseje una inspección sobre el terreno de los bienes o derechos a valorar, en las que necesariamente tienen que participar los vocales que señala el art. 4.3.a) y b) ${ }^{68}$. La prórroga la acuerda la Comisión, en la sesión en la que se reúna para adoptar el acuerdo de valoración y, en todo caso, antes de la expiración del plazo previsto para adoptar y notificar el acuerdo. El acuerdo debe ser motivado, se notifica a las partes y debe incorporarse al expediente un certificado al efecto (art. 12.2 del Reglamento). En todo caso, ha de considerarse la aplicación del art. 42 de la Ley 30/1992.

Transcurrido el plazo, puede entenderse desestimada la pretensión del expropiado (art. 12.3 del Reglamento).

El Reglamento configura una suerte de silencio administrativo negativo que merece algún comentario ${ }^{69}$. En primer término, hay que considerar si el silencio se produce también cuando es la Administración quien inicia el procedimiento. En segundo lugar, conviene cuestionarse si es el silencio administrativo la figura que debe entrar en juego cuando se produce esta falta de acuerdo de la Comisión en el plazo establecido al efecto. Por último, habría que tener en cuenta si el expropiado pierde la oportunidad de ver incrementado el justiprecio. Trataré de todo ello en el siguiente epígrafe.

\section{EL INCUMPLIMIENTO DE LA OBLIGACIÓN DE ADOPTAR EL ACUERDO EN PLAZO}

Como se acaba de indicar, transcurrido el plazo de que dispone la Comisión para adoptar el acuerdo de valoración, puede entenderse desestimada la

\footnotetext{
${ }^{68}$ Esta previsión se inspira en el art. 23 del Decreto del País Vasco 244/1988.

${ }^{69}$ Esta ha sido también la opción de la legislación del Principado de Asturias (art. 13.3 del Decreto 22/2004), Castilla-La Mancha (art. 13 del Decreto 41/2003), Cataluña (art. 12.5 del Decreto 202/2000), Galicia (art. 232 de la Ley 9/2002) y Navarra (art. 126.5 de la Ley Foral 35/2002, de 20 de diciembre, de Ordenación del Territorio y Urbanismo). Para J. I. GARCÍA CAMPÁ y J. LLIDÓ SILVESTRE (1995, p. 648) el silencio debía ser positivo.
} 
pretensión del expropiado. Sin perjuicio de lo que más adelante se expondrá sobre el acierto o no de la opción que acoge el Reglamento, lo primero que debe plantearse es a qué se refiere la disposición cuando nos habla de "la pretensión del expropiado". Si se interpreta la expresión de la norma en sentido estricto, hay que entender que la ficción que habilita para acudir a la Jurisdicción Contencioso-Administrativa se produce sólo en los casos en que la expropiación se inicia por ministerio de la Ley. Sin embargo, esta interpretación estricta no ampara los supuestos en que la pasividad de la Administración se ciñe a la falta de presentación de las hojas de aprecio ${ }^{70}$ y, en términos más generales, los casos en que, iniciado un expediente expropiatorio de oficio, la Comisión no adopta el acuerdo de valoración ${ }^{71}$. Por ello, debe realizarse una interpretación más amplia que englobe estos casos, entendiendo, pues, que la pretensión del expropiado es siempre, con independencia de cómo se inicie la expropiación -de oficio o por ministerio de la Ley- la obtención del justiprecio, como demanda además el sentido común. Por consiguiente, el mismo tratamiento debe recibir cualquier pasividad de la Administración, ya sea la concerniente a la incoación del expediente expropiatorio (expropiación por ministerio de la Ley), la relativa a la falta de remisión de las hojas de aprecio o la que se cifra en la no adopción en plazo del acuerdo de fijación de justiprecio. Todo ello con independencia, además, de otras consideraciones que pudieran hacerse acerca de que también es la Administración -o en su caso el beneficiario- la que puede ver frustradas sus pretensiones con la inactividad de la Comisión ${ }^{72}$.

La siguiente cuestión que se plantea es la de si el silencio administrativo es una técnica correcta para hacer frente a la inactividad de la Comisión, solución ésta que, por otra parte, se inspira en la STC 136/1995, de 25 de septiembre ${ }^{73}$.

70 Como se recordará, al respecto hemos propugnado que el expropiado pueda presentar la hoja de aprecio ante la Comisión.

${ }^{71}$ Se trataría de un supuesto de caducidad ex art. 44 de la Ley 30/1992. Cabe cuestionarse, sin embargo, la bondad de esta solución, habida cuenta de que la mayoría de las expropiaciones siguen el procedimiento de urgencia y de la extensión que en el ámbito urbanístico tiene la previa ocupación.

72 Ya que en el procedimiento expropiatorio ordinario -el menos ordinario de los procedimientos expropiatorios- la Administración tampoco podrá ocupar el bien.

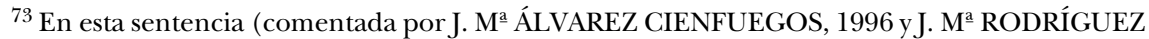
DE SANTIAGO, 1996) el Tribunal partió de la consideración de las resoluciones de los Jurados Provinciales como actos administrativos y estimó que la denuncia de la mora efectuada por el particular no podía considerarse sólo a los efectos del devengo de intereses ex art. 56 de la Ley de Expropiación Forzosa (precepto que por otra parte no exige tal denuncia de mora), puesto que no 
En mi opinión, no estamos en puridad ante un supuesto de silencio administrativo, puesto que de suyo no hay una auténtica petición o solicitud del administrado $^{74}$, ni tampoco se trata de un procedimiento iniciado de oficio por la Administración y susceptible de producir efectos favorables en el administrado $^{75}$. En este sentido, puede resultar útil recordar la Disposición Adicional vigésimo novena de la Ley 14/2000, que en su apartado cuarto excluye del régimen del silencio administrativo a la terminación convencional de procedimientos administrativos, así como los de mediación, arbitraje y conciliación: aunque con ello no quiero manifestar que la actividad de las Comisiones responda a estas categorías, sí me parece que guarda cierta semejanza o similitud. En cualquier caso, muy posiblemente la opción del Reglamento de aplicar al supuesto la técnica del silencio administrativo obedezca tan sólo a razones de economía procesal, lo que trae como consecuencia deferir al órgano judicial

cabía descartar su "validez como manifestación reaccional del administrado por la que se interesa que la Administración ponga remedio a su inactividad" (F.J. $\left.4^{\circ}\right)$. Argumentó además que del procedimiento ante el Jurado "pueden derivarse efectos favorables para el expropiado, que éste ha sido parte en el referido procedimiento y en él ha formulado una valoración de los bienes expropiados mediante la hoja de aprecio a la que no cabe negar características materiales de petición y, en fin, que en este caso el procedimiento trae causa de una previa actuación de gravamen de la Administración -que conlleva nada menos que la ocupación de la finca sin consignación previaque produce sin duda una minoración de la esfera jurídica del particular" (F.J. $4^{\circ}$ ).

74 Vid. en este sentido la STS de 22 de febrero de 1993, AR. 843, sobre la que se pronunció la STC 136/1995. La sentencia del Tribunal Supremo argumenta también que los Jurados no están incardinados en la organización jerárquica de la Administración y que, en mérito de ello, tampoco les resulta de aplicación la doctrina del silencio. A juicio de J. M ${ }^{\mathrm{a}}$ RODRÍGUEZ DE SANTIAGO (1996, pp. 228 ss.), la sentencia realiza aquí "un inexplicable salto lógico"; el autor, por otra parte, señala que en las expropiaciones urbanísticas de terrenos destinados a dotaciones públicas "habría menos problemas para admitir la técnica del silencio", si bien concluye que "no es serio hacer depender las normas de acceso a la jurisdicción del carácter, urbanístico o no, de la expropiación de que se trate".

${ }^{75}$ No fue ésta la opinión del Tribunal Constitucional en la ya citada sentencia 136/1995: a juicio del Tribunal, del procedimiento iniciado ante el Jurado pueden derivarse efectos favorables para el expropiado; sin embargo, también afirma la existencia de una previa actuación de gravamen de la Administración (F.J. $4^{\circ}$ ). Según P. CANCER MINCHOT (2004, p. 33), es "un procedimiento que, además de ser de oficio, puede tener resultados favorables para cualquiera de las partes (pues el Jurado puede acoger las pretensiones del expropiado, o bien las del beneficiario)". En realidad se trata de una cuestión de perspectiva: el procedimiento expropiatorio es un procedimiento que pudiéramos calificar, en principio, de gravamen, mientras que la fijación del justiprecio tiene la connotación de favorable. En cualquier caso, aun se podría discutir si hay un procedimiento (el expropiatorio) o dos con sustantividad propia: el expropiatorio y, dentro de éste, el de fijación de justiprecio ante el Jurado o la Comisión Provincial. 
la fijación del justiprecio ${ }^{76}$, aunque también, nótese bien, sujetar a plazo el acceso a la Jurisdicción Contencioso-Administrativa ${ }^{77}$.

A mi juicio, se trataría, más propiamente, de un supuesto de inactividad de la Administración, que en teoría al menos debería recibir el tratamiento que prescribe el art. 29 de la Ley de la Jurisdicción ${ }^{78}$, de modo que, a la postre, el órgano judicial debería condenar a la Administración a resolver ${ }^{79}$. Interesa destacar, en apoyo de esta opinión, que la STC 36/1995 matizó que el proceso por la inactividad del Jurado no tenía que concluir siempre y en todo caso con una sentencia en la que se fijara el justiprecio, puesto que a los Tribunales "para la satisfacción del derecho a la tutela del recurrente les puede bastar con ponderar, en cada supuesto, las circunstancias causantes de la inactividad administrativa en relación con los perjuicios que de aquélla se puedan derivar para los derechos e intereses legítimos del administrado, reconociendo, en su caso, su derecho a que el Jurado de Expropiación resuelva en plazo, y adoptando, en el trámite de ejecución de Sentencia, las medidas necesarias para reparar esa inactividad de la Administración” (F.J. $\left.4^{\underline{o}}\right)^{80}$. No obstante, el

\footnotetext{
${ }^{76}$ F. SOSA WAGNER (2003, p. 181) que manifiesta que se trata de un supuesto de inactividad, señala, no obstante, que el expropiado puede solicitar a los Tribunales contenciosos la determinación del justiprecio y la condena al pago del mismo, pues "no satisfaría el derecho fundamental a la tutela judicial efectiva que el recurso del expropiado sólo consiguiera una condena de la Administración para que el Jurado resolviera el expediente". El autor, por tanto, auna el objeto del recurso contencioso-administrativo en el supuesto de inactividad de la Administración con el contenido de la sentencia en el caso de anulación de actos administrativos.

77 Vid, no obstante, la STS de 23 de enero de 2004, comentada por E. M. PÉREZ ANDRÉS (2004). Aunque la sentencia declara no haber lugar a un recurso de casación en interés de Ley (y por tanto carece de los efectos propios de esta clase de recursos), en su F.J. $3^{\circ}$ indica que "en tanto las Administraciones Públicas no informen a los interesados de los extremos a que dicho precepto se refiere [el art. 42.4.2 ${ }^{\circ}$ de la Ley 30/1992] los plazos para la interposición de los recursos no empiezan a correr". De todos modos, cabe cuestionar que el citado precepto pueda recoger el supuesto de la fijación del justiprecio.
}

${ }^{78}$ En igual sentido vid. F. SOSA WAGNER, 2003, pp. 180 y 189. F. GARCÍA GÓMEZ DE MERCADO (2004, p. 120) parece admitirlo, aunque inmediatamente descarta la posibilidad.

${ }^{79}$ Lo que en modo alguno procede es entender producida, en casos de demoras excesivas, la prescripción del derecho del expropiado, como en alguna ocasión se ha argumentado. El Tribunal Supremo ha salido al paso de esta interpretación (STS de 17 de mayo de 1993, AR. 3752, cit. por F. SOSA WAGNER, 2003, p. 95).

${ }^{80}$ En esta línea cabe citar la STS de 22 de febrero de 1995 (AR. 768), citada por J. M. RODRÍGUEZ DE SANTIAGO (1996, pp. 230 y 231) 
recurso a la figura de la inactividad tiene el inconveniente de que se vuelva a suscitar una nueva inactividad de la Administración, ahora en fase de ejecución de sentencia; en este caso, sería el órgano judicial el que terminaría fijando el justiprecio, al amparo del art. 108.1.a) de la $\mathrm{LJCA}^{81}$; a la postre, pues, la solución sería la misma a la que se llega desde la consideración de la omisión de la Administración como un supuesto de silencio administrativo.

La otra opción, configurar el supuesto como un caso de silencio negativo, me parece más voluntarista ${ }^{82}$ y no tiene en la actualidad el sentido de antaño, una vez que efectivamente nuestro Ordenamiento contempla en términos más amplios la inactividad de la Administración ${ }^{83}$.

En cualquier caso, cabe plantearse si el Reglamento se excede de la competencia que ostenta la Comunidad Autónoma para regular sus Comisiones Provinciales de Valoración, pues por esta vía, según se ha señalado, se atribuye a los Tribunales la competencia para fijar el justiprecio ${ }^{84}$.

La última cuestión apuntada en relación con la calificación de la pasividad de la Comisión como silencio negativo se refiere a si, en virtud de este me-

\footnotetext{
${ }^{81}$ Incluso el Tribunal podría, al amparo del mismo art. 108.1.a), requerir la colaboración del Jurado Provincial de Expropiación.

Discrepo aquí de F. GARCÍA GÓMEZ DE MERCADO, quien entiende que el justiprecio fijado por el Tribunal en fase de ejecución de sentencia "constituirá la indemnización de daños y perjuicios ocasionados por la falta de su fijación, en cuanto el expropiado se ve privado de sus bienes y derechos sin valoración y pago de los mismos" (ob. cit. p. 120). Como ya he indicado, sería de aplicación el art. 108.1.a) LJCA; no considero que entre en juego la institución de la responsabilidad administrativa.
}

\footnotetext{
82 Prueba de ello es que en este Reglamento el silencio se entiende producido con el simple transcurso del tiempo, mientras que al amparo de la LEF, antes desde luego de la LJCA, se ha venido entendiendo que los expropiados "han de incitar un acto, aunque se presunto, y para ello, percibido cierto transcurso de tiempo sin que exista decisión del Jurado han de presentar ante el mismo o ante la Administración actuante una solicitud para que bien su resolución o bien su silencio permita abrir la puerta de la jurisdicción" (vid. F. SOSA WAGNER, 2003, p. 180, que cita la STS de 20 de junio de 1997, AR. 4712). Vid. también el Auto del Tribunal Constitucional 409/1988, de 18 de abril.

83 Vid., pero con referencia al Proyecto de Ley Reguladora de la Jurisdicción Contencioso-Administrativa (BOCG de 30 de septiembre), J. Mª RODRÍGUEZ DE SANTIAGO, 1996, p. 236.

${ }^{84}$ Duda de la constitucionalidad de las normas de las Comunidades Autónomas que regulan esta cuestión F. GARCÍA GÓMEZ DE MERCADO (ob. cit. p. 122), si bien porque considera que es materia propia de procedimiento administrativo (art. 149.1.18 CE).
} 
canismo, el expropiado que acude a la Jurisdicción pierde la posibilidad de acrecer el justiprecio, en su caso y en su día, con los intereses de demora. En mi opinión no, pues la garantía que formula el art. 56 LEF es común para todos los expropiados, con independencia de cómo se articule en concreto el procedimiento expropiatorio y, más concretamente, con la solución que se ofrezca al incumplimiento del deber de fijación del justiprecio. Ha de tenerse en cuenta, además, que el art. 56 citado tipifica como supuesto de hecho determinante del nacimiento del derecho a los intereses de demora el transcurso de seis meses "desde la iniciación legal del expediente expropiatorio sin haberse determinado por resolución definitiva el justo precio de las cosas o derechos", que es lo que precisamente ocurre cuando se entiende producido el silencio negativo. Estos intereses debe abonarlos la Administración autonómica, aun cuando se trate de una expropiación local o exista un beneficiario de la expropiación.

Cabe también plantearse si el silencio de la Administración excluye la aplicación del art. 15.3 del Reglamento. Este precepto se remite, en los supuestos de expropiaciones urbanísticas en las que concurra avenencia entre las partes con base en la propuesta efectuada, a lo dispuesto en el artículo 166.1 de la Ley de Ordenación Urbanística de Andalucía, que prescribe que en caso de existir avenencia en la fijación del justiprecio se estará a lo dispuesto en el artículo 120.3 de la Ley, que a su vez señala que "en todo caso, la aceptación por el expropiado del precio ofrecido por la Administración actuante o su concesionario en el plazo concedido al efecto determinará el reconocimiento y pago de éste incrementado en un diez por ciento”. En mi opinión, una vez fijado el justiprecio por el Tribunal, debe incrementarse en el diez por ciento que estos preceptos prevén, pues el recurso del expropiado a la Jurisdicción no tiene como finalidad discutir la cuantía del mismo sino, más sencillamente, conseguir su fijación, siquiera sea por el órgano judicial.

\section{EL ACUERDO DE FIJACIÓN DE JUSTIPRECIO}

El acuerdo, finalmente, debe estar motivado, con expresa justificación de los criterios empleados para la valoración, con relación a la normativa que resulte de aplicación (art. 17 del Reglamento) ${ }^{85}$. No se exige que los miembros

\footnotetext{
${ }^{85}$ La jurisprudencia, en palabras de F. SOSA WAGNER (2003, pp. 182 ss.) ha sido "muy flexible y tolerante a la hora de analizar la motivación de los acuerdos del Jurado", como lo acreditan las sentencias que el autor cita. Vid. también F. GARCÍA GÓMEZ DE MERCADO, 2004, pp. 79 ss.
} 
que discrepen del voto mayoritario de la Comisión deban motivar el sentido de su voto $^{86}$. El acuerdo pone fin a la vía administrativa (art. 16.2 del Reglamento).

Contra el acuerdo cabe recurso contencioso-administrativo, previo recurso de reposición potestativo, en principio ante el Juzgado de lo ContenciosoAdministrativo (art. $8.3 \mathrm{LJ}$ ), puesto que las Comisiones son órganos de carácter desconcentrado, de ámbito provincial (DA 3 $3^{a} .1$ LOUA y art. 1 del Reglamento). Sin embargo, la literalidad de la $\mathrm{LJ}^{87}$, criticada por la doctrina ${ }^{88}$, ha sido corregida por los autos del Tribunal Supremo de 24 de junio (JUR 2002 216873) y 11 de noviembre de 2002 (RJ 2003\1115), citados por J. $M^{\mathbf{a}}$ MACÍAS CASTAÑO ${ }^{89}$. Con arreglo a la doctrina contenida en estos autos, las resoluciones de los órganos periféricos de las Comunidades Autónomas en materia de expropiación forzosa son recurribles ante los Tribunales Superiores de Justicia.

En el curso del proceso contencioso-administrativo, la Administración expropiante podrá defender la valoración ofrecida en su hoja de aprecio, en lugar de defender la decisión de la Comisión; en consecuencia, la sentencia puede reducir la cuantía del justiprecio original sin que ello se califique como $r$ formatio in peius ${ }^{90}$. El expropiado, por otra parte, podrá extender la impugna-

${ }^{86}$ Como prescribe el art. 13.2 del Decreto de la Comunidad de Madrid 71/1997, que de este modo establece una importante garantía para los sujetos de la expropiación. En el mismo sentido se pronuncian el art. 13 del Decreto 41/2003, de Castilla-La Mancha y el art. 13 del Decreto 22/2004 del Principado de Asturias.

${ }^{87}$ La reforma producida en el art. 8.3 por la Ley Orgánica 19/2003, de 23 de diciembre, no ha contemplado la competencia en esta materia de los Tribunales Superiores de Justicia, a diferencia de lo que sucede respecto de la Administración del Estado.

88 Vid. C. PICO LORENZO (2001, pp. 149 ss.); la autora comenta el Auto de 4 de mayo de 1999, recurso 2511/1998, de la Sección Primera de la Sala de lo Contencioso-Administrativo del Tribunal Superior de Justicia de Cataluña, así como el Auto de 4 de junio, desestimatorio del recurso de súplica contra el anterior. En estos Autos se razona el carácter periférico de las secciones territoriales del Jurado de Expropiación Forzosa de Cataluña, precisándose que el calificativo "periférico" se utiliza en la Ley de la Jurisdicción en sentido material, no formal, "como alternativa a los órganos centrales y definidos exclusivamente por el ámbito territorial al que extienden su competencia” (Auto de 4 de junio de 1999, cit. por C. PICO LORENZO, p. 154).

Un comentario crítico al desigual tratamiento de los recursos en materia de expropiación forzosa, según quien sea quien fije el justiprecio, puede verse en J. A. DOMÍNGUEZ LUIS, 2002.

89 2003, pp. 171 y 172.

90 Vid. F. SOSA WAGNER, 2003, p. 191. 
ción a los actos previos que hayan tenido lugar, incluso a los que hayan producido de forma implícita la declaración de utilidad pública o interés social y al acuerdo de necesidad de ocupación. Esta posibilidad, que viene siendo admitida por los Tribunales y la doctrina ${ }^{91}$, encuentra refrendo en el Reglamento que regula las Comisiones, en la medida en que permite que la Comisión se pronuncie sobre la naturaleza expropiatoria del expediente.

Por último, la Administración autonómica habrá de efectuar la previa declaración de lesividad (arts. 43 LJCA y 103 LRJAP); la Administración local, en su caso, podrá interponer directamente el recurso contencioso, sin efectuar el requerimiento que regula el art. 44 LJCA, ya que la Administración autonómica no podría, en ningún caso, modificar el acuerdo de la Comisión ${ }^{92}$.

\section{BIBLIOGRAFÍA}

ÁLVAREZ CIENFUEGOS, JOSÉ MARÍA. "Los actos del jurado provincial de expropiación forzosa y el silencio administrativo: una vuelta a los principios", Revista Jurídica Española La Ley, 1996, D-45, pp. 1709 a 1712.

ARANA GARCÍA, ESTANISLAO y CUESTA REVILLA, JOSÉ. "La ejecución de los instrumentos de planeamiento", Derecho Urbanistico de Andalucía (Comentarios a la Ley 7/2002, de 17 de diciembre, de Ordenación Urbanistica de Andalucia)", Tirant Lo Blanch, Valencia, 2003, pp. 273 a 489.

CALVO CHARRO, MARÍA. "La imparcialidad del Jurado de Expropiación: comentario crítico a la jurisprudencia del Tribunal Supremo", Revista Española de Derecho Administrativo núm. 78, 1993, pp. 343 a 355.

CANCER MINCHOT, PILAR. "El procedimiento expropiatorio: problemas actuales y su intento de solución en el borrador del anteproyecto de la LEF", La Ley de Expropiación Forzosa. Análisis y perspectivas de reforma, Ministerio de Hacienda, Madrid, 2003, pp. 117 a 131.

"Efectos económicos negativos del sistema actual de determinación del justiprecio expropiatorio, y sus posibles soluciones", Aspectos económicos de la jurisdicción contencioso-administrativa, Consejo General del Poder Judicial, Madrid, 2004, pp. 13 a 37.

91 Vid. F. GARCÍA GÓMEZ DE MERCADO, 2004, pp. 86 ss.

92 Vid. en este sentido F. SOSA WAGNER, 2003, p. 190. Ha de tenerse en cuenta que tanto la LOUA como el Decreto que las regula reconocen la plena autonomía funcional de las Comisiones. 
DOMÍNGUEZ LUIS, JOSÉ ANTONIO. "Jurados de Expropiación Forzosa y competencia jurisdiccional: el artículo 8.3 de la Ley Reguladora de la Jurisdicción Contencioso-administrativa", Revista Jurídica de la Comunidad de Madrid, núm. 14, 2002 (consultada en Internet).

FERNÁNDEZ RODRÍGUEZ, TOMÁS RAMÓN. "Notas sobre el proceso continuo y silencioso de erosión del Derecho estatal y de las garantías jurídicas de los ciudadanos: el caso de los Jurados autonómicos de Expropiación", Revista de Administración Pública núm. 153, 2000, pp. 91 a106.

FERNÁNDEZ TORRES, JUAN RAMÓN. "La expropiación forzosa por razón del urbanismo: régimen jurídico general y singularidades de la legislación andaluza”, Derecho Urbanistico de Andalucía, La Ley-Actualidad, Madrid, 2004, pp. 595 a 652.

GARCÉS SANAGUSTÍN, MARIO. "Los jurados provinciales de expropiación: análisis retrospectivo y alternativas para su mejora”, La Ley de Expropiación Forzosa. Análisis y perspectivas de reforma, Ministerio de Hacienda, Madrid, 2003, pp. 175 a 200.

GARCÍA CAMPÁ, JOSÉ IGNACIO y LLIDÓ SILVESTRE, JOAQUÍN, "El Jurado de Expropiación: aportaciones críticas y alternativas", Revista de Estudios de la Administración Local y Autonómica, núm. 267, 1995, pp. 627 a 649 .

GARCÍA DE ENTERRÍA, EDUARDO. "La Ley de Expropiación Forzosa de 1954, medio siglo después”, Revista de Administración Pública núm. 156, 2001, pp. 251 a 268.

GARCÍA GÓMEZ DE MERCADO, FRANCISCO. El justiprecio de la expropiación forzosa. Estudio de su valoración y pago, con especial consideración de las expropiaciones urbanisticas, Ed. Comares, $5^{\underline{a}}$ ed., Granada, 2004.

MACÍAS CASTAÑO, JOSÉ MARÍA. "Expropiaciones urbanísticas: procedimiento, valoraciones y reversión", Derecho y Urbanismo: principios e instituciones comunes, Cuadernos de Derecho Judicial X-2003, Consejo General del Poder Judicial, Madrid, 2003, pp. 133 a 228.

MÚGICA HERZOG, ENRIQUE. "El Defensor del Pueblo y la expropiación forzosa", La Ley de Expropiación Forzosa. Análisis y perspectivas de reforma, Ministerio de Hacienda, Madrid, 2003, pp. 19 a 38. 
PÉREZ ANDRÉS, ELOíSA MARÍA. "Una sentencia trascendental sobre la inexistencia de plazo para interponer el recurso contencioso-administrativo frente al silencio administrativo negativo", Revista de Administración Pública núm. 164, 2004, pp. 201 a 210.

PICO LORENZO, CELSA. "Una aproximación a los Jurados de Valoración Autonómicos desde la perspectiva del Derecho procesal y orgánico”, Revista de Administración Pública núm. 155, 2001, pp. 149 a163.

PRIETO GONZÁLEZ, LUIS FERNANDO. "La ejecución pública del planeamiento", Derecho Urbanístico de Canarias, Instituto de Estudios Canario, Tenerife, 2003, pp. 247 a 268.

RODRÍGUEZ DE SANTIAGO, JOSÉ MARÍA. "Otro embate contra el carácter revisor: el recurso contencioso-administrativo ante el incumplimiento por el Jurado Provincial de Expropiación de la obligación de fijar el justiprecio en plazo (STC 136/1995, de 25 de septiembre)", Revista de Administración Pública núm. 139, 1996, pp. 221 a 236.

SOSA WAGNER, FRANCISCO. "Artículo 25. El expediente de justiprecio", Comentarios a la Ley de Expropiación Forzosa, Ed. Aranzadi, 2aㅡ ed., Navarra, 2003, pp. 93 a 98.

“Artículo 30. Procedimiento de determinación del justiprecio", ibidem, pp. 127 a 135.

"Artículo 31. Procedimiento de determinación del justiprecio", ibidem, pp. 135 a 140.

“Artículo 32. Los Jurados de Expropiación”, ibidem, pp. 141 a 157.

“Artículo 33. Los Jurados de Expropiación”, ibidem, pp. 158 a 171.

"Artículo 34. Procedimiento ante el Jurado de Expropiación”, ibidem pp. 171 a 181.

VV.AA. Ley de Ordenación Urbanística de Andalucía: estudio preliminar, comentarios a su articulado y formularios, coordinado por A. PÉREZ MARÍN y P. SÁNCHEZ NÚÑEZ, Ed. Comares, Granada, 2003. 